\title{
Subacute sclerosing leukoencephalitis
}

INSERM

\section{Source}

INSERM. (1999). Orphanet: an online rare disease and orphan drug data base. Subacute sclerosing leukoencephalitis. ORPHA:2806

Subacute sclerosing panencephalitis (SSPE) is a chronic progressive encephalitis that develops a few years after measles infection and presents with a demyelination of the cerebral cortex. 